\title{
Corynebacterium sphenisci sp. nov., isolated from wild penguins
}

\author{
J. Goyache, ${ }^{1}$ C. Ballesteros, ${ }^{1}$ A. I. Vela, ${ }^{1}$ M. D. Collins, ${ }^{2}$ V. Briones, ${ }^{1}$ \\ R. A. Hutson, ${ }^{2}$ J. Potti, ${ }^{3}$ P. García-Borboroglu, ${ }^{4}$ L. Domínguez ${ }^{1}$ \\ and J. F. Fernández-Garayzábal ${ }^{1}$ \\ ${ }^{1}$ Departamento de Patología Animal I (Sanidad Animal), Facultad de Veterinaria, Universidad \\ Complutense, 28040 Madrid, Spain \\ ${ }^{2}$ School of Food Biosciences, University of Reading, Reading RG6 6AP, UK \\ ${ }^{3}$ Departamento de Biología Animal, Universidad de Alcalá, Alcalá de Henares, 28871 Madrid, \\ Spain \\ ${ }^{4}$ CENPAT-CONICET, Bv. Brown s/n, Puerto Madryn, Chubut, Argentina
}

Correspondence

J. F. Fernández-Garayzábal garayzab@vet.ucm.es
The genus Corynebacterium has undergone considerable expansion in recent years and now represents one of the largest genera within the Actinobacteria. Currently, the genus accommodates in excess of 50 species, more than 30 of which have been described during the last decade. In the past, the recognition of novel corynebacteria was problematic due to limitations in the taxonomic tests (primarily morphological and biochemical) used to identify these organisms. However, in recent years, the implementation of molecular identification methods (in particular 16S rRNA gene sequencing) in concert with improved phenotypic approaches has greatly facilitated the discovery of novel species diversity. The great majority of the novel species that have been described in recent years have originated from human (e.g. Collins et al., 1999a; Funke et al., 1997a, 1998; Renaud et al., 2001; Sjödén et al., 1998) and, to a lesser extent, animal sources (e.g. Fernández-Garayzábal et al., 1997, 1998; Pascual et al., 1998; Collins et al., 1999b,

The GenBank/EMBL/DDBJ accession number for the $16 \mathrm{~S}$ rRNA gene sequence of strain CECT $5990^{\top}$ is AJ440964. 2001a,b). Despite this rapid expansion, it is clear that much corynebacterial diversity from human and animal sources remains to be discovered (e.g. Tanner et al., 1999). In the course of an on-going study of unusual Actinobacteria from wild animals, we have characterized a hitherto unknown Corynebacterium species from magellanic penguins (Spheniscus magellanicus). Based on the results of a polyphasic taxonomic study, a novel Corynebacterium species, Corynebacterium sphenisci sp. nov., is described.

Six unidentified Gram-positive, rod-shaped organisms were recovered from the cloacae of healthy wild penguins. Samples from cloacae were collected with sterile swabs with transport medium and kept under refrigeration until being processed in laboratory within $6 \mathrm{~h}$. Strains were isolated on Columbia blood-agar plates (bioMérieux) and incubated for $24 \mathrm{~h}$ at $37^{\circ} \mathrm{C}$ under aerobic and anaerobic conditions. The unknown isolates were recovered from the cloacal samples together with Staphylococcus sciuri. The unidentified strains were grown on Columbia blood-agar plates at $37^{\circ} \mathrm{C}$ under aerobic conditions and were 
characterized biochemically by using the API CORYNE (version 2.0), API $50 \mathrm{CH}$ and API ZYM systems according to the manufacturer's instructions (bioMérieux). Incubation of the API $50 \mathrm{CH}$ strips was extended up to $72 \mathrm{~h}$. The CAMP test with Staphylococcus aureus ATCC 25923 was carried out according to standard procedures (Funke et al., 1997b). Lipophilic requirements were determined by growing the isolates on brain heart infusion agar supplemented with $1 \%$ Tween 80 in comparison with brain heart infusion agar lacking lipid supplementation. Cell-wall murein was prepared by mechanical disruption of cells and complete acid hydrolysates were analysed as described by Schleifer \& Kandler (1972). Fatty acid methyl esters were prepared and analysed as described by Kämpfer \& Kroppenstedt (1996). The presence of mycolic acids was investigated by GLC analysis of trimethylsilylated derivatives (TMS-MAME) (Klatte et al., 1994). For phylogenetic analysis, a large fragment of the 16S rRNA gene of the isolates was amplified by PCR and sequenced directly using a Taq DyeDeoxy terminator cycle sequencing kit (Applied Biosystems) and an automatic DNA sequencer (model 373A; Applied Biosystems). The closest known relatives of the novel isolates were determined by performing a database search. A phylogenetic tree was constructed according to the neighbourjoining method with the program NEIGHBOR (Felsenstein, 1989). The stability of groupings was estimated by bootstrap analysis (500 replications) using the programs DNABOOT, DNADIST, NEIGHBOR and CONSENSE (Felsenstein, 1989).

The unidentified rod-shaped organisms from penguins stained Gram-positive and displayed a coryneform morphology. The isolates were non-motile and did not form endospores. They grew on sheep-blood agar at $37^{\circ} \mathrm{C}$, forming small (approx. 1-2 mm diameter after $48 \mathrm{~h}$ incubation), whitish, low-convex, dry and rough colonies that were non-haemolytic. The isolates were catalase-positive, nonlipophilic and CAMP-test-negative. Using commercially available API systems, the isolates failed to hydrolyse aesculin, gelatin or urea. All of the strains reduced nitrate and produced acid from glucose, maltose, galactose, D-fructose, D-mannose and trehalose, but not from xylose, ribose, mannitol, lactose, sucrose or glycogen. Activity for pyrazinamidase, esterase C4, ester lipase C8, lipase C14, leucine arylamidase, valine arylamidase, cystine arylamidase, chymotrypsin, acid phosphatase and naphthol-AS-BI phosphohydrolase was observed. No activity was detected for alkaline phosphatase, pyrrolidonyl arylamidase, $\alpha$-glucosidase, $\beta$ glucosidase, $\beta$-glucuronidase, $N$-acetyl- $\beta$-glucosaminidase, $\alpha$-mannosidase, $\alpha$-galactosidase, $\beta$-galactosidase, $\alpha$ fucosidase or trypsin. The morphological and biochemical characteristics of the isolates were consistent with their tentative assignment to the genus Corynebacterium. The unknown strains gave a numerical profile with the API CORYNE system of 3000124 that corresponds to a good identification of Corynebacterium striatum/Corynebacterium amycolatum. However, the isolates were readily differentiated from the latter two species by their inability to produce acid from sucrose and to produce alkaline phosphatase. By contrast, C. striatum and C. amycolatum are positive for both of these tests (Martínez-Martínez et al., 1995; Funke et al., 1996). Additionally, C. amycolatum produces acid from ribose, while the unidentified isolates are negative for this test (Funke et al., 1996). Analysis of the amino acid composition of the cell-wall murein of a representative isolate (strain CECT $5990^{\mathrm{T}}$ ) revealed mesodiaminopimelic acid as the dibasic acid, which reinforces its provisional assignment to the genus Corynebacterium. The major long-chain cellular fatty acids of the organism were $\mathrm{C}_{12: 0}(3 \%), \mathrm{C}_{14: 0}(4 \%), \mathrm{C}_{16: 0}(28 \%), \mathrm{C}_{18: 0}(25 \%)$, $\mathrm{C}_{18: 1} \omega 9 c(28 \%), \mathrm{C}_{18: 1} \omega 7 c(1 \%)$ and $\mathrm{C}_{20: 0}(2 \%)$. Small

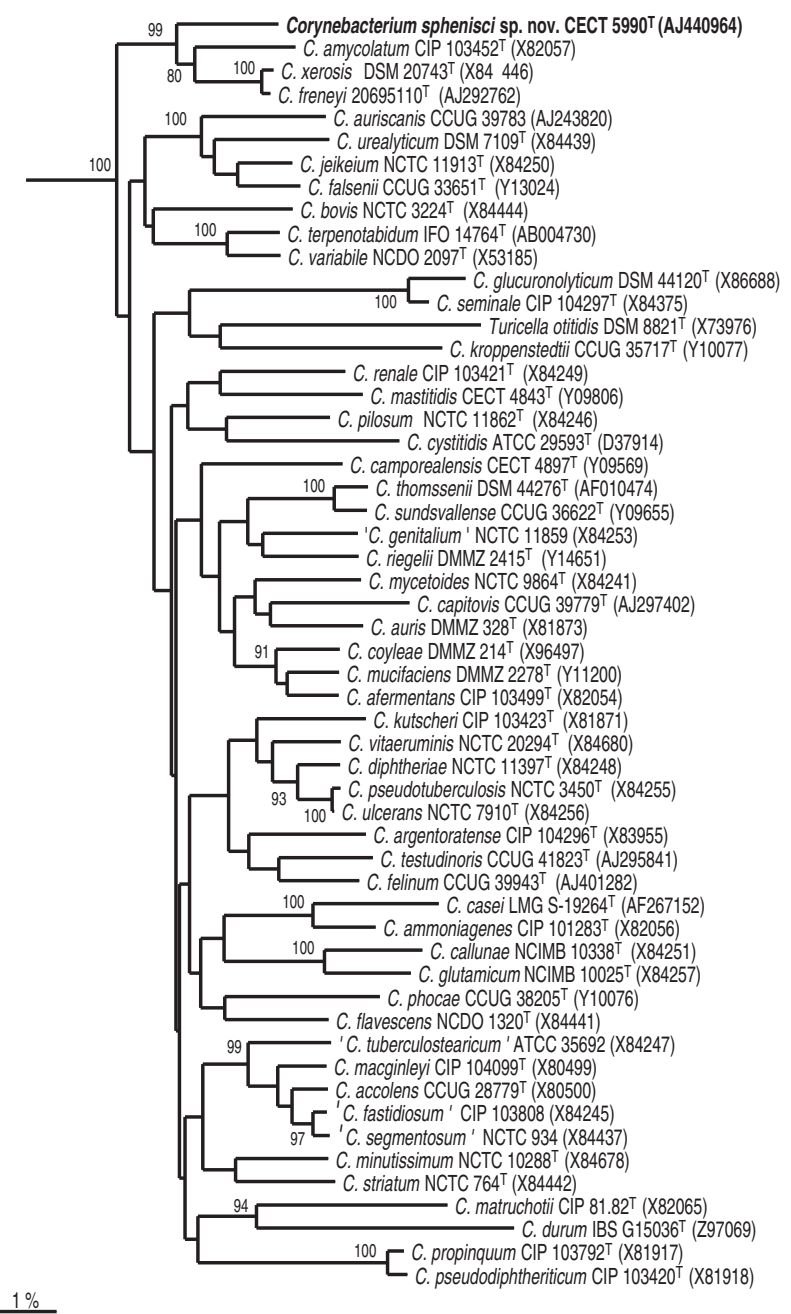

Fig. 1. Unrooted tree based on 16S rRNA gene sequences showing the phylogenetic relationships of Corynebacterium sphenisci sp. nov. Bootstrap values (expressed as percentages of 500 replications) are given at branching points. The tree was rooted using outgroup sequences (not shown) from Gordonia amarae DSM 43392 ${ }^{\top}$ (X80635), Tsukamurella paurometabola DSM 20162 ${ }^{\top}$ (X53207), Nocardia asteroides DSM 43005 (X53205) and Rhodococcus erythropolis NCIMB $11148^{\top}$ (X76691). Bar, $1 \%$ sequence divergence. 
amounts of short-chain mycolic acids $\left(\mathrm{C}_{22}-\mathrm{C}_{32}\right)$ were also detected. The wall murein and lipid composition of the penguin bacterium strongly resembled those of corynebacteria.

To ascertain the phylogenetic position of the unknown isolates, 16S rRNA gene sequencing was performed. For strain CECT $5990^{\mathrm{T}}$, the almost complete sequence was determined $(>1400 \mathrm{nt})$, whereas approximately 1000 nucleotides were determined for each of the other isolates. Comparative sequence analysis revealed 99.9-100 \% sequence similarity between the strains, thereby demonstrating their high genealogical relatedness. Sequence searches of EMBL/GenBank databases confirmed that the unknown strains were members of the genus Corynebacterium, with other actinomycete taxa showing lower levels of relatedness (data not shown). Treeing analysis demonstrated the placement of the unidentified bacterium (as exemplified by strain CECT $5990^{\mathrm{T}}$ ) within the genus Corynebacterium. A tree constructed using the neighbour-joining method depicting the phylogenetic position of the unidentified bacterium is shown in Fig. 1 and shows unequivocally that it represents a distinct subline associated with a small group of species that includes C. amycolatum, Corynebacterium xerosis and Corynebacterium freneyi (respectively exhibiting $96 \cdot 2,97 \cdot 0$ and $96 \cdot 3 \%$ sequence similarity to the penguin bacterium).

The results of the polyphasic taxonomic analysis clearly show that the unknown bacteria isolated from the cloacae of penguins represents a hitherto unrecognized species within the genus Corynebacterium. Phylogenetically, the bacterium forms a novel subline closely associated with C. amycolatum, C. xerosis and C. freneyi. Bootstrap resampling revealed the affinity between the unknown penguin bacterium and the aforementioned cluster of species to be statistically significant (value $99 \%$ ), which, together with sequence divergence values of $3 \%$ or greater, demonstrates unequivocally that the isolates represent a distinct Corynebacterium species. The unknown bacterium can also be easily distinguished phenotypically from all other Corynebacterium species described to date. Therefore, based on both phenotypic and phylogenetic evidence, we propose that the bacteria from penguins be assigned to the genus Corynebacterium, as Corynebacterium sphenisci sp. nov. Tests that serve to distinguish C. sphenisci from its closest phylogenetic relatives are shown in Table 1.

\section{Description of Corynebacterium sphenisci sp. nov.}

Corynebacterium sphenisci (sphe.nis'ci. N.L. masc. gen. n. sphenisci of Spheniscus, a systematic genus of penguins, indicating the source of the type strain).

Cells stain Gram-positive and consist of non-motile, nonspore-forming rods. Colonies are whitish, low-convex, dry and rough and approximately $1-2 \mathrm{~mm}$ in diameter after $48 \mathrm{~h}$ incubation at $37^{\circ} \mathrm{C}$ on sheep-blood agar. Facultatively anaerobic. Non-haemolytic, non-lipophilic and CAMPnegative. Catalase-positive and oxidase-negative. Nitrates are reduced. Acid is produced from glucose, maltose, galactose, fructose, mannose and trehalose, but not from ribose, sucrose, glycogen, xylose, mannitol, lactose, erythritol, D-arabinose, L-arabinose, adonitol, galactose, L-sorbose, rhamnose, inositol, sorbitol, methyl $\alpha$-D-mannoside, methyl $\alpha$-D-glucoside, amygdalin, dulcitol, arbutin, salicin, cellobiose, melibiose, inulin, melezitose, D-raffinose, xylitol, $\beta$-gentiobiose, D-turanose, D-lyxose, D-tagatose, D-fucose, L-fucose, D-arabitol, L-arabitol, $\mathrm{N}$-acetylglucosamine, 2-ketogluconate, 5-ketogluconate or glycerol. Gelatin, urea and aesculin are not hydrolysed. Activity for pyrazinamidase,

Table 1. Characteristics that differentiate Corynebacterium sphenisci sp. nov. from its closest phylogenetic relatives and from C. striatum

Characteristics are scored as: +, positive; -, negative; V, variable; S, susceptible; R, resistant; ND, not determined.

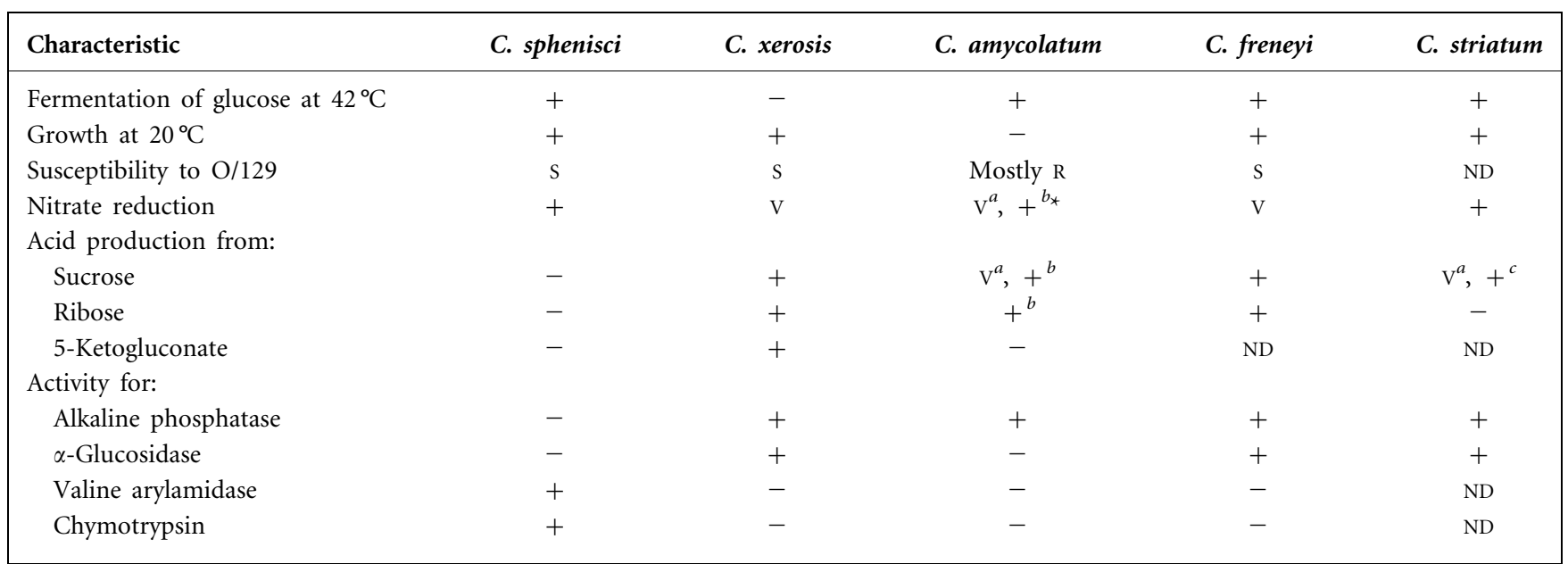

*Sources of data taken from other studies are indicated as: a, Funke et al. (1997b); b, Funke et al. (1996); c, Martínez-Martínez et al. (1995). 
esterase C4, ester lipase C8, lipase C14, leucine arylamidase, valine arylamidase, cystine arylamidase, chymotrypsin, acid phosphatase and naphthol-AS-BI phosphohydrolase is detected. No activity is detected for alkaline phosphatase, pyrrolidonyl arylamidase, $\alpha$-glucosidase, $\beta$-glucosidase, $\beta$ glucuronidase, $N$-acetyl- $\beta$-glucosaminidase, $\alpha$-mannosidase, $\alpha$-galactosidase, $\beta$-galactosidase, $\alpha$-fucosidase or trypsin. Cell-wall murein is based on meso-diaminopimelic acid. Long-chain cellular fatty acids are primarily of the straight-chain saturated and monounsaturated types, with $\mathrm{C}_{16: 0}, \mathrm{C}_{18: 0}$ and $\mathrm{C}_{18: 1} \omega 9 c$ as the major components. Tuberculostearic acid is not present. Corynomycolic acids are produced, but in small amounts.

The type strain, CECT $5990^{\mathrm{T}}$ (=CCUG $46398^{\mathrm{T}}$ ), was isolated from the cloaca of an apparently healthy wild magellanic penguin (Spheniscus magellanicus).

\section{References}

Collins, M. D., Bernard, K. A., Hutson, R. A., Sjödén, B., Nyberg, A. \& Falsen, E. (1999a). Corynebacterium sundsvallense sp. nov., from human clinical specimens. Int J Syst Bacteriol 49, 361-366.

Collins, M. D., Hoyles, L., Lawson, P. A., Falsen, E., Robson, R. L. \& Foster, G. (1999b). Phenotypic and phylogenetic characterization of a new Corynebacterium species from dogs: description of Corynebacterium auriscanis sp. nov. J Clin Microbiol 37, 3443-3447.

Collins, M. D., Hoyles, L., Foster, G., Sjödén, B. \& Falsen, E. (2001a). Corynebacterium capitovis sp. nov., from a sheep. Int J Syst Evol Microbiol 51, 857-860.

Collins, M. D., Hoyles, L., Hutson, R. A., Foster, G. \& Falsen, E. (2001b). Corynebacterium testudinoris sp. nov., from a tortoise, and Corynebacterium felinum sp. nov., from a Scottish wild cat. Int J Syst Evol Microbiol 51, 1349-1352.

Felsenstein, J. (1989). PHYLIP - phylogeny inference package (version 3.2). Cladistics 5, 164-166.

Fernandez-Garayzabal, J. F., Collins, M. D., Hutson, R. A., Fernandez, E., Monasterio, R., Marco, R. \& Dominguez, L. (1997). Corynebacterium mastitidis sp. nov., isolated from milk of sheep with subclinical mastitis. Int J Syst Bacteriol 47, 1082-1085.

Fernández-Garayzábal, J. F., Collins, M. D., Hutson, R. A., Gonzalez, I., Fernández, E. \& Domínguez, L. (1998).
Corynebacterium camporealensis sp. nov., associated with subclinical mastitis in sheep. Int J Syst Bacteriol 48, 463-468.

Funke, G., Lawson, P. A., Bernard, K. A. \& Collins, M. D. (1996). Most Corynebacterium xerosis strains identified in the routine clinical laboratory correspond to Corynebacterium amycolatum. J Clin Microbiol 34, 1124-1128.

Funke, G., Lawson, P. A. \& Collins, M. D. (1997a). Corynebacterium mucifaciens sp. nov., an unusual species from human clinical material. Int J Syst Bacteriol 47, 952-957.

Funke, G., von Graevenitz, A., Clarridge, J. E., III \& Bernard, K. A. (1997b). Clinical microbiology of coryneform bacteria. Clin Microbiol Rev 10, 125-159.

Funke, G., Osorio, C. R., Frei, R., Riegel, P. \& Collins, M. D. (1998). Corynebacterium confusum sp. nov., isolated from human clinical specimens. Int J Syst Bacteriol 48, 1291-1296.

Kämpfer, P. \& Kroppenstedt, R. M. (1996). Numerical analysis of fatty acid patterns of coryneform bacteria and related taxa. Can J Microbiol 42, 989-1005.

Klatte, S., Kroppenstedt, R. M. \& Rainey, F. A. (1994). Rhodococcus opacues sp. nov., an unusual nutritionally versatile Rhodococcus species. Syst Appl Microbiol 14, 355-360.

Martínez-Martínez, L., Suárez, A. I., Winstanley, J., Ortega, M. C. \& Bernard, K. (1995). Phenotypic characteristics of 31 strains of Corynebacterium striatum isolated from clinical samples. J Clin Microbiol 33, 2458-2461.

Pascual, C., Foster, G., Alvarez, N. \& Collins, M. D. (1998). Corynebacterium phocae sp. nov., isolated from the common seal (Phoca vitulina). Int J Syst Bacteriol 48, 601-604.

Renaud, F. N. R., Aubel, D., Riegel, P., Meugnier, H. \& Bollet, C. (2001). Corynebacterium freneyi sp. nov., $\alpha$-glucosidase-positive strains related to Corynebacterium xerosis. Int J Syst Evol Microbiol 51, 1723-1728.

Schleifer, K. H. \& Kandler, O. (1972). Peptidoglycan types of bacterial cell walls and their taxonomic implications. Bacteriol Rev 36, 407-477.

Sjödén, B., Funke, G., Izquierdo, A., Akervall, E. \& Collins, M. D. (1998). Description of some coryneform bacteria isolated from human clinical specimens as Corynebacterium falsenii sp. nov. Int J Syst Bacteriol 48, 69-74.

Tanner, M. A., Shoskes, D., Shahed, A. \& Pace, N. R. (1999). Prevalence of corynebacterial $16 \mathrm{~S}$ rRNA sequences in patients with bacterial and "nonbacterial" prostatitis. J Clin Microbiol 37, 1863-1870. 